\title{
A LOJALITÁS VIZSGÁLATA FOGYASZTÁSSZOCIOLÓGIAI SZEMPONTBÓL
}

A szerzó célja, hogy fogyasztásszociológiai szempontból magyarázza a lojalitást, különös tekintettel annak problémás és ellentmondásos területeire. Tanulmánya problémafelvetố jellegú, nem kíván konkrét magyarázatokkal szolgálni a lojalitással kapcsolatos eddigi ellentmondásokra, sokkal inkább egy olyan új megvilágításba szeretné helyezni a témát, amely megfelelő alapot nyújt késốbbi kutatásokhoz, és ezáltal a lojalitás alaposabb megismeréséhez.

\section{Kulcsszavak: fogyasztás, fogyasztásszociológia, lojalitás}

Tanulmányomban arra a napjainkban egyre népszerúbbé váló kérdésre keresem a választ, hogy miért lesz lojális egy fogyasztó adott termékhez vagy márkához. Ezt a kérdést sokan sokféleképpen elemezték. Az elmúlt évtized egyik legnépszerúbb témaköre volt a fogyasztói lojalitás, az ezredfordulóra egyre többen tekintettek rá úgy, mint a siker kulcsára. A lojalitást az elégedettség mögötti - vagy akár azt helyettesítő - sikerre vezetô stratégiai célnak vélték. A lojalitásnak és a lojalitásvizsgálatoknak azonban számos korlátja és problémája van. Tanulmányom elsô részében ilyen ellentmondásokat mutatok be.

Ezeket a problémákat azonban nem azzal a céllal ismertetem, hogy cáfoljam a lojalitás híveinek állításait, hanem fel kívánom hívni a figyelmet arra, hogy a szakirodalmon belül számos ellentmondás tapasztalható a lojalitáskutatások terén. Véleményem szerint ezeknek a problémáknak jelentôs része abból ered, hogy nincs egy jól meghatározott fogalmi keret vagy egy nézópont, ami alapján vizsgálnák a lojalitást. Nincs egyértelmú magyarázat arra, hogy mitôl lesz lojális egy fogyasztó, a lojalitás idóben hogyan változik, illetve adott esetben miért szúnik meg?

Tanulmányom megírása során az a gondolat vezérelt, hogy kell lennie a lojalitás mögött húzódó valamilyen magyarázó tényezőnek, amely egyértelmúbben meghatározza, hogy mitôl, és fốként miért lesz lojális a fogyasztó. Hitem szerint ezt a tényezôt vagy motivátort megtalálva a lojalitással kapcsolatos ellentmondások egy jelentôs részét is fel lehet oldani. Kutatásaim alapján a fogyasztásszociológiához jutottam, és ezen belül is a szimbolikus fogyasztáshoz, mely magyarázó tényezô lehet a lojalitásra vonatkozóan. Elemzéseim során nem kívánok olyan megalapozatlan kijelentésekbe bocsátkozni, hogy egyértelmúen és ellentmondásoktól mentesen meg lehet magyarázni a lojalitást fogyasztásszociológiai alapon, azonban úgy vélem, egy olyan kiindulási alapra leltem, ahonnan elindulva érdekes megállapításokhoz lehet eljutni.

Tanulmányom elsố részében áttekintem a lojalitással kapcsolatos elméleteket és bemutatom a lojalitás jelentőségét napjaink gazdasági viszonyai között. Ezt követően mutatok rá a lojalitás kérdéskörével kapcsolatos problémákra, ellentmondásokra.

A második részben a fogyasztásszociológia alapjait mutatom be, illetve a tanulmányhoz kapcsolódó megállapításait elemzem, különös tekintettel a szimbolikus fogyasztásra. Ezen a fogyasztásszociológiai alapon állva megvizsgálom a lojalitás jelenségét és kapcsolatát a szimbolikus fogyasztással. Végezetül jövóbeli kutatási irányokat és elemzendó kérdéseket veszek sorra, melyekkel a késóbbiekben behatóbban kívánok foglalkozni, annak reményében, hogy közelebb visznek a fogyasztó döntéshozatalának megismeréséhez. 


\section{A lojalitás}

\section{A lojalitás definíciói és típusai a szakirodalomban}

Neal szerint a vevői lojalitás egy viselkedésmód, melyet azzal az aránnyal mérnek, hogy a fogyasztó vásárlásai során az összes adott típusú termékvásárlás hányadrészét teszi ki a vizsgált termék vagy márka (Neal, 1999). Az így definiált lojalitás tehát elsősorban az ismételt vásárlásokból indul ki.

Oliver tágabban értelmezi a fogalmat: „A lojalitás a tartós preferencia elérésének állapota, mely a határozott márkavédésig terjed" (Oliver, 1999: p. 41-42.). A tartós preferencia szintén az újravásárlásra utal, azonban megjelenik egy ezen túlmutató jelenség, a márkavédés is, mely fogalmat a szerzô a pozitív szájreklám analógiájaként értelmezi.

A magyar szakirodalomban Hetesi és Rekettye foglalkozott behatóan a lojalitás kérdéskörével. Kutatásaik során megemlítik az újravásárlási szándékot, a keresztvásárlásokat, az árérzékenységet és a másoknak való ajánlást mint a lojalitás fogalmi elemeit (Hetesi Rekettye, 2005). A definiálás magja ebben az esetben is a vásárlás, melyen belül az újravásárlás mellett az elpártolás tényezőit (keresztvásárlás, árrugalmasság) is feltüntetik, valamint újdonságként jelenik meg a másoknak való ajánlás mint lojalitási kritérium.

Reichheld szinte a lojalitás egészét a Hetesi és Rekettye által említett negyedik tényezôvel magyarázza. Szerinte a lojalitás nem feltétlenül jelent újravásárlást, sokkal inkább népszerúsítést. Az igazi lojalitás több az ismételt újravásárlásnál, mert ez utóbbi lehet pusztán lustaságból, illetve kényszerúségból is, monopolista piac esetén (Reichheld, 2003).

Oliver (1999) a lojalitásnak különböző típusait különbözteti meg, és a típusok közül kiemel egy úgynevezett ,,végső́ lojalitást”, mely azt jelenti, hogy a fogyasztó bármilyen körülmények között, bármilyen áron, csak a vizsgált terméket vagy szolgáltatást vásárolja meg. A kategorizálásnál két dimenzió mentén alakít ki négy lojalitástípust. E két dimenzió az egyéni elkötelezettség és a társadalom lojalitástámogató szerepe:

- Ha gyenge az egyén márka iránti elkötelezettsége, illetve gyenge a társadalom lojalitástámogató szerepe, akkor a kialakuló lojalitás alapja pusztán a termékelőny, a termékminóség. Megjegyzendó, hogy korábban ezt tekintették a lojalitás egészének, vagyis a lojalitás nem más, mint a magas minőségból adódó termékelőny újravásárlása. Olivernél ez a típus „gyenge lojalitásnak" minősül, melyból kiderül, hogy a tényleges lojalitás a korábbi értelmezésnél jóval összetettebb jelenség.
- Ha erôs az egyén márka iránti elkötelezettsége, illetve gyenge a társadalom lojalitástámogató szerepe, akkor a végsố lojalitás személyes, belső alkotóeleméhez jutunk. Oliver szerint ebben az esetben az egyén belsô, exkluzív és folyamatosan ismétlődő kapcsolatra törekszik a választott márkával. Fontos kiemelni, hogy ebben az esetben ez a motiváció személyes eredetú, melyet a szerzô a szerelemhez és a rajongáshoz hasonlít. Úgy is meg lehet fogalmazni a helyzetet, hogy a vevő lojális akar lenni.

- Ha gyenge az egyén márka iránti elkötelezettsége, de erós a társadalom lojalitástámogató szerepe, akkor az egyén passzív elfogadója a márka lojális környezetének. Ebben az esetben a közös fogyasztásból kialakuló közösségtudat az irányító erô. Ez a másik fontos tényezóje a végső lojalitásnak. Erre a helyzetre az a jellemzó, hogy a környezete akarja, hogy a vevő lojális legyen.

- Ha erős az egyén márka iránti elkötelezettsége, illetve erős a társadalom lojalitástámogató szerepe, akkor összhangban áll az egyén belsố törekvése a környezete által elvárt viselkedéssel, ami nagyon erôs lojalitáshoz vezet, mely gyakorlatilag a végső lojalitás előszobája.

A fenti tipizálást Oliver a következóképpen foglalja össze: „A fogyasztó termékhez kapcsolódó, valamint személyes, továbbá szociális lojalitási elemekkel jellemezhetố. A szociális elem az erődítménye, a saját jelleméhez kapcsolódó elem a pajzsa, míg a termékelőny a fegyvertára. Ezek közül bármelyiket vesszük is el, a fogyasztó védtelenné válik a konkurencia csábító támadásaival szemben" (Oliver, 1999).

\section{Miért hasznos a lojalitás a vállalat sikere szem- pontjából?}

Kutatások bizonyítják (Oliver, 1999; Reichheld, 1996), hogy egy új vevő́ megszerzésének költsége ötszöröse egy korábbi vevô megtartásáénak. Reichheld számos vállalatra kiterjedő vizsgálatából kiderül, hogy a visszatérő vevốk számának 5\%-os növekedése esetén a profitnövekedés 25-100\% közötti (Reichheld, 2000). Ez nem azt jelenti, hogy azért nem járható a klasszikus út (azaz folyamatosan új vevốk megszerzésére törekedni), mert nem lehet új fogyasztókat szerezni, hanem azt, hogy drágább lett a vevók megszerzésének akvizíciós költsége, és ezzel párhuzamosan megemelkedett a visszatérő vevốk szerepe a hosszú távú sikerességben.

A Reichheld (2000) által használt „customer lifetime value”, azaz a „vevő életciklusértéke” kifejezés jól ragadja meg lojalitás profitra gyakorolt befolyását. En- 
nek lényege, hogy meghatározható egyes vevốkre nézve életük során a vállalat számára nyújtott profit menynyisége, mely a vállalat és az adott vevő közt lezajlott tranzakciókból származó profitok kumulált összege. A vevô életciklusértéke nyilvánvalóan annál magasabb, minél több tranzakció zajlott le az adott fogyasztó és a vállalat között. Ezt a gondolatmenetet folytatva arra a megállapításra jut, miszerint a vevók $10 \%$-a hozza a profit 50-70\%-át (Reichheld, 2000; 2003).

Összefoglalva tehát hatékonyabb azon vevốk személyes igényeire koncentrálni, akik nagymértékben hozzájárulnak életciklusuk alatt a vállalati profithoz. Ezeket a vevóket nevezem összefoglalóan a vállalat számára stratégiailag fontos, „profitabilis” vevóknek. Ezen túlmenően, a lojalitás növeli a cég jövedelmezőségét, mert a lojális vevốk megtartásának költsége alacsonyabb, mint az új vevớk akvizíciós költsége, továbbá a hưséges vevő kevésbé árérzékeny, jó hírét kelti a cégnek, és az idő előrehaladtával általában növeli vásárlási volumenét (Hetesi - Rekettye, 2005; Reichheld, 2000; 2003; Reichheld et al., 2003; Oliver, 1999; Zeithaml et al., 2004; Jaishankar et al., 2000; Newman, 2001).

\section{A lojalitással kapcsolatos problémák, ellentmondások a szakirodalomban}

A '90-es években egyre nagyobb teret hódított a marketing-szakirodalomban az a nézet, hogy a korábban fontosnak tartott elégedettség önmagában nem járul hozzá a vállalat hosszú távú profitjához, ehelyett a lojalitásra kell koncentrálni, ez ugyanis az a tényezó, amely döntően befolyásolja a sikert (Reichheld, 2000; Oliver, 1999; Neal, 1999). Az ezzel kapcsolatosan végzett kutatások a lojalitást kiemelkedően szignifikáns profitnövelő tényezóként aposztrofálták, ennek hatására mindent elsöprő jelentőségének gondolata gyorsan elterjedt. Az ezredfordulót követôen azonban a lojalitás kezd arra a sorsa jutni, mint korábban az elégedettség, vagyis egyre több tanulmány születik arra vonatkozólag, hogy jelentőségét túlbecsülték. A lojalitással kapcsolatos problémák és ellentmondások közül szeretnék bemutatni néhányat. Ezzel az a célom, hogy rávilágítsak arra, hogy a lojalitás jelenleg elterjedt értelmezése korántsem egyértelmú kulcs a sikerhez.

\section{A lojalitás nem minden cég számára érhetố el}

Oliver (1999) több szempontból is méltatja a lojalitás jelentôségét a vállalat hosszú távú sikere szempontjából, de felhívja a figyelmet arra, hogy nem lehet általános sikerstratégiának tekinteni. Kutatásai alapján arra a következtetésre jut, hogy a vállalatok egy része számára nehezen elérhetố a lojalitás, így téves lenne azt célnak tekinteni. Számukra az elégedettséget ja- vasolja mint elérhetố célt (Oliver, 1999). Azonban azt Oliver sem határozza meg konkrétan, hogy mely vállalatoknak lehet stratégiai célja a lojalitás, és melyeknek nem. Szintén ellentmondásos ezzel kapcsolatban, hogy Reichheld - aki Oliverrel a legtöbb esetben azonos állásponton van - tanulmányaiban azt bizonyítja, hogy nemcsak, hogy nem jelent hasznot a vállalat számára, ha maximalizálja vevooinek elégedettségét, hanem egyenesen káros hatással lesz a hosszú távú profitra. Ezt nevezi az „elégedettség csapdájának”" (Reichheld, 2000). Az elégedettség mint csapda gondolata azonban igen ellentmondásos fényt vet Oliver fent említett javaslatára, miszerint a cégek egy részének a magas elégedettséget kell stratégiai célul kitúznie.

\section{A lojalitással kapcsolatos kutatási eredmények korlátozott használhatósága}

A lojalitással kapcsolatos vizsgálatok a szakirodalomban szinte minden esetben egy vagy néhány meghatározott ágazaton belül zajlanak le. Ennek következtében az eredményekkel kapcsolatosan folyamatosan felmerül az a probléma, hogy az adott ágazattal kapcsolatos lojalitási jellemzóket meghatározzák ugyan, azonban ezek az eredmények csak korlátozottan alkalmasak arra, hogy más ágazatok esetében is magyarázzák a lojalitást. Ennek szélsőséges eseteiben előfordul, hogy más-más ágazatban végzett lojalitásvizsgálatok ellentétes eredményekre vezetnek a lojalitást meghatározó tényezőkben.

A szakirodalomban számos esetben alapvetôen különböznek a B2B és a B2C piacon végzett lojalitásvizsgálatok megállapításai (Hetesi - Rekettye, 2005; Reinartz - Kumar, 2002). Gyakran élnek a szerzók azzal a kitétellel a vizsgálati eredmények alapján történő következetések levonásakor, hogy ezek az eredmények csak az adott ágazaton belül alkalmazhatóak, esetleg hozzátéve, hogy nagy valószínúség szerint más ágazatokban is hasonló eredményekre lehetne jutni (Reinartz - Kumar, 2002).

Összességében tehát komoly korlátját jelenti a lojalitással kapcsolatos elemzéseknek az a tény, hogy az ezzel kapcsolatos kutatási eredmények ágazatfüggókk, és ebból adódóan korlátozottan alkalmazhatók.

\section{A dinamizálás és az intertemporalitás hiánya a lojalitásvizsgálatokban}

A lojalitás jelentőségének méltatásakor leggyakrabban azt hangsúlyozzák, hogy jelentős szerepe van a hosszú távú profit alakításában (Reichheld, 1996, 2000, 2003; Oliver, 1999). Sok esetben hiányzik azonban az intertemporális vizsgálat ezzel kapcsolatban, így figyelmen kívül hagyják a technológia változását, illetve az 
egyéni preferenciákban bekövetkezô idóbeli változásokat (Jaishankar et al., 2000). Még a legnagyobb márkák is ki vannak téve a fogyasztó ízlésében bekövetkező változások veszélyének, így egy téves innováció, vagy pusztán az önelégültség is tragikus következményekkel járhat (Newman, 2001).

Pusztán attól, hogy egy fogyasztó a múltban lojális volt, nem következtethetünk arra, hogy a jövőben is az lesz. Sốt a vállalatok által a fogyasztói lojalitás mérésére leggyakrabban alkalmazott RFM-rendszer (recency, frequency, monetary value) eredményeinek alkalmazása hosszú távon a profitnövekedéssel ellentétes hatást fejthet ki. Ez a rendszer ugyanis a fogyasztókat aszerint rangsorolja, hogy egy adott időperióduson belül, a vállalattal hány alkalommal és milyen összegú tranzakcióban vettek részt. Ez alapján azonban a vállalat marketing-eróforrásait olyan fogyasztókra is „pazarolja”, akik korábban lojálisak voltak, az idő előrehaladtával azonban elpártoltak, így a rájuk fordított magas marketingköltségek nem térülnek meg (Reinartz - Kumar, 2002).

Zeithaml még ennél is messzebbre megy, ugyanis azt állítja, hogy az cég, amelyik túlzottan ragaszkodik vásárlóihoz, és akár újrapozícionálja termékét, annak érdekében, hogy megtartsa lojális vevơbázisát, hosszú távon veszteséget fog realizálni. Véleménye szerint, a vállalatnak nem arra kell törekednie, hogy megtartsa a márkához korábban lojális vevóket, hanem arra, hogy a vevók igényeivel együtt változzon, és ha kell, akkor egy-egy „elhasználódott” márkát vonjon ki a piacról, ebben az esetben a korábban ehhez a márkához húséges vevóit más - a vállalathoz tartozó - márka felé kell terelni. Elismeri tehát, hogy az adott márkához kapcsolódó lojalitás hosszú távon sok esetben nem tartható fenn (Zeithaml et al., 2004).

Még ennél is komolyabb támadásnak tekinthetô Reinartz és Kumar tanulmánya, melyben a szerzók alapvetôen kérdőjelezik meg a lojalitás hosszú távú jövedelmezőségét. Kutatásaikat B2B és B2C piacon egyaránt elvégezték és arra a következtetésre jutottak, hogy a lojális fogyasztókkal kapcsolatos költségek magasabbak, mint az átlagfogyasztóval kapcsolatosak, továbbá megállapították, hogy nincs szignifikáns kapcsolat az árérzékenység és a lojalitás között. Ezen túlmenôen utalnak rá, hogy a vállalat „új” és „régi” vevői között nincs jelentős különbség a szájreklámban. Kutatási eredményeik ismertetésekor természetesen ók is kikötötték, hogy ezek a megállapítások, csak az általuk vizsgált négy ágazatban bizonyítottak. Azért tértem ki mégis külön az ő kutatási eredményeikre, mert két érdekes jelenségre hívták föl a figyelmet. Egyrészt arra, hogy a lojális vevő́k jelentős része vár valami viszon- zást - gyakran anyagi természetút - húségéért cserébe. Másrészt arra, hogy 54\%-kal nagyobb arányban népszerúsítették a céget azok, akik nemcsak az újravásárlási szokásaik miatt kerültek be a lojális vásárlók közé, hanem ezen felül még önmagukat lojálisnak is vallották (Reinartz - Kumar, 2002). Ennek a két jelenségnek a késôbbi elemzések során fogyasztásszociológiai jelentőséget tulajdonítok.

Mindenképpen probléma tehát, hogy a lojalitás múló jelenség, és hosszú távon profitveszteséghez vezethet, ha feltételezzük, hogy egy korábban lojális vevốt a végsókig lehet - vagy érdemes - a márkához láncolni. Ehhez kapcsolódik a következő probléma.

\section{A lojális vevók elpártolása}

Még a lojalitás legelfogultabb hívei sem állítják azt, hogy kiküszöbölhetô a korábban lojális vevốk elpártolása. Oliver (1999) beszél ugyan ,végső lojalitásról”, azonban errôl az állapotról sem állítható, hogy soha nem fog elpártolni a vevő, ugyanis ez bizonyos értelemben irracionális állapot, amit a konkurencia is kihasznál, és elcsábítja a fogyasztót (Hetesi, 2002).

A lojalitás hívei gyakran hangsúlyozzák, hogy a fogyasztó szempontjából ez egyfajta kockázatcsökkentő magatartás. Napjaink túltelített piacán ugyanis, szinte minden esetben, alulinformált helyzetben hoz döntést a fogyasztó, és ekkor a korábbi bevált márka választásával elkerülheti az ismeretlen termék kipróbálásához kapcsolódó veszélyeket (Kovács, 2000). Newman (2001) azonban ebben a helyzetben felhívja a figyelmet a lojalitással ellentétes magatartás racionalitására. Összetett és nehezen átlátható piaci helyzetben ugyanis a fogyasztó szempontjából ideálisnak túnhet, ha az ár alapján hozza meg döntéseit, vagy egyszerúen váltogatja a márkákat, ezzel csökkentve annak kockázatát, hogy lemarad valamely új, jobb minőségú termékről.

Jaishankar és szerzôtársai (2000) behatóan tanulmányozzák a lojális fogyasztók elpártolásának jelenségét. Véleményük szerint, a lojális fogyasztók csoportján belül is több kategória létezik, és az egyéni jellemző́k alapján, eltérő módon viselkedhetnek lojális fogyasztók a jövóben. Arra a megállapításra jutnak, hogy a lojális vevôbázison belül kialakíthatók szegmensek, és ezek alapján meghatározhatók azok a jellemzók, melyekból a késóbbi márkaelhagyás eredeztethető. Különbséget tesznek az elégedett elpártolók és az elégedetlen elpártolók között. Megállapításaik szerint az elpártolási hajlandóságra komoly hatással van a fogyasztó termékhez kapcsolódó érintettsége (,involvement”-je). Kutatásaik alapján arra a következtetésre jutnak, miszerint az elpártolók esetében 
alacsonyabb a személyes érintettség, mint a hosszú távon hüségesek esetén. Ennek a megállapításnak is tulajdonítok fogyasztásszociológiai jelentôséget tanulmányom második részében.

\section{A fogyasztásszociológia}

\section{A fogyasztásszociológia rövid bemutatása}

Annak ellenére, hogy mind a szociológia, mind a közgazdaságtan aránylag régóta létezô tudományágak, a fogyasztásszociológia, mint e két terület határán elhelyezkedô tudomány, igen rövid múltra tekint vissza. Ennek egyik oka, hogy a közgazdászok nem igazán törekedtek szociológiai elemek beépítésére modelljeikbe, ezzel ugyanis egy viszonylag nehezen számszerúsíthetô, kevésbé egzakt elemet kellett volna vizsgálniuk. Másik oldalról pedig a szociológusok is tartózkodtak a fogyasztás vizsgálatától, ugyanis a fogyasztási kultúrát egy kizsákmányolásra alapuló modern kapitalista kultúrának vélték, melynek materialista értékrendje nem volt összeegyeztethető a szociológusok világnézetével (Campbell, 1996).

A fogyasztásszociológia előfutárának tekinthető Thorsten Veblen, aki a múlt század elején a státusszimbólumok jelentôségét vizsgálva megállapította, hogy a fogyasztás a korról, nemról, személyiségról és hangulatról is szolgál információval (Veblen, 1925).

A fogyasztásszociológia mint tudományterület létrejötte a XX. század második felére tehető, melyhez szociológiai oldalról hozzájárult a feminizmus és a hozzá kapcsolódó kutatások megjelenése és térnyerése, tekintve, hogy akkoriban úgy vélték, a fogyasztási döntések többségét hölgyek hozzák meg, így a feminizmus vizsgálata a szociológiában magával hozta a fogyasztás elemzését is (Campbell, 1996).

Emellett a posztmodern irányzat is befolyásolta e fiatal tudományág térnyerését, ugyanis a posztmodern társadalmat Kaplan (1987) és Featherstone (1991) a fogyasztói társadalommal vélte analógnak. A posztmodern gondolkodók a fogyasztást inkább szimbolikus és nem instrumentális cselekvésnek tartották.

A világszerte végbemenô változások eredményeképpen a XX. század második felére a termelés által irányított gazdaság átalakult fogyasztás által irányítottá. A fogyasztóknak ugyanis az egyre bővülő választékból egyre nagyobb szabadságuk volt választani, ezáltal döntéseik váltak a vállalati profit fố befolyásolójává. Az értékesítoók érzékelték a kereslet változásait, ezt továbbították a gyártók felé, így befolyásolva a termék-előállítást. Ezzel tehát a korábbi termelésorientált gazdaságból fogyasztásorientált gazdaság alakult ki (Miller, 1996; Campbell, 1996).
Ezek a változások alapjaiban érintették a gazdasági szemléletet. A fogyasztókat nem tekintették többé haszonmaximalizáló automatáknak, akik pusztán információs inputokat alakítanak át márkaválasztási outputtá. A társadalmi osztályokat a késóbbiekben nem úgy vizsgálták, mint értékesítési szempontból eltérô módszerekkel célba vehetô csoportokat, hanem mint olyan egységeket, melyekben megjelenik a szegénység, a jólét, a kohézió, az integráció, a csoporthoz tartozás, valamint a kirekesztettség egyaránt, ezáltal befolyásolva az egyének vágyait és igényeit. Felismerték továbbá, hogy egy gépkocsi nem pusztán egy közlekedési eszköz, hanem egyúttal a szabadság, a státus, a szórakozás, az erô, a kapcsolat, az erószak és még sok egyéb tényező együttes megtestesítője. Összességében tehát elkezdték vizsgálni, hogy a fogyasztás milyen szerepet tölt be az egyén teljes életében, ezáltal életre hívták a fogyasztásszociológia tudományát (Belk, 1996).

Veblen nyomán, a XX. század második felében, többek között Solomon (1988) és McCracken (1986) is rávilágított arra, hogy az egyén fogyasztása információval szolgál a fogyasztó személyiségéról az egyén és környezete számára egyaránt. Az egyes fogyasztási javaknak nem pusztán önállóan van jelentőségük, hanem a teljes fogyasztási konstelláció kifejezi fogyasztójának életstílusát (Belk, 1996).

A gazdasági és társadalmi rendszer ebbéli változása azt is jelentette, hogy a társadalom szervezóerejének szerepét a termeléstól a fogyasztás vette át, ugyanis ebben a társadalomban a fogyasztás magas szintje testesíti meg a sikert és a személyes boldogságot, így egyszersmind a fogyasztás vált az egyének életcéljává (Campbell, 1996; Cherrier - Murray, 2004).

Baudrillard $(1981,1988)$ a fogyasztásra nem úgy tekint, mint a javak megszerzése, hanem mint a jelek birtokbavétele. Az egyén külső megjelenéséből a szemlélő „le tudja olvasni" annak társadalmi státusát, ezzel Baudrillard, arra a megállapításra jut, hogy a jelenkor társadalmában modern változatban jelennek meg a feudális társadalomszervezó erók, vagyis a jelek és a szimbólumok.

Belkhez (1996) hasonlóan Baudrillard (1981, 1988) is azon az állásponton van, hogy a jelek nem önmagukban értelmezendőek, ugyanis napjainkra már elszakadtak a képviselt dologtól, melyhez korábban szorosan kapcsolódtak, így mostanra csak egymásra hatnak, és csak együtt nyernek értelmet. Példaként említi a nyakkendôt, ami lehet az arisztokratikus elitizmus vagy a puritán munkásélet szimbóluma egyaránt. Baudrillard a társadalmi osztálytagozódást is a jelek által vezéreltnek tekinti, ugyanis azok alkotnak egy koherens társadalmi csoportot, akiknek azonosak a kódjaik, ebból kifolyólag egy adott jelet ugyanúgy értelmeznek. 


\section{A szimbolikus fogyasztás}

A vevốk nem a konkrét terméktulajdonságokat mérlegelik, hanem azt, hogy mit nyernek a termék fogyasztásával (Farkas, 2003). A vevő tehát valóban értékre vágyik, de nem arra, hogy a fogyasztással a ráfordításánál többet nyerjen, hanem arra, hogy megkapja azt az értéket, ami kielégíti vágyát. Ez a vágy, és ezáltal a vágy kielégítésére szolgáló érték is igen erôs szimbolikus tartalommal is bír. Milyen lehet ez a szimbolikus tartalom?

A termékszimbolizmus két dimenzióját különbözteti meg Bell - Holbrook - Solomon (1991). Az egyik az esztétikai vagy hedonikus érték, amelyhez kapcsolódó érzések a fogyasztónak nem mások miatt, hanem saját maga miatt fontosak, vagyis ez az érték belsố motiváción alapul. A másik a társadalmi vagy státust biztosító érték, amely bizonyos termékek fogyasztása során arra szolgál, hogy a kívánt benyomást keltse másokban - ez tehát külsố motivációkhoz kapcsolódik.

Nietzschénél is megjelenik a szimbolizmus, mely tulajdonképpen egyfajta stratégia (Nietzsche ezt „,apollóni stratégiának" nevezte), mellyel az ember, aki mint befejezetlen lény, vagy „,még meghatározatlan állat", igyekszik kulturális szimbólumok segítségével elhelyezkedni a számára idegen világban. Napjainkra ezek a szimbólumok termékekben testesülnek meg, és széles körben elérhetôvé váltak (Törốcsik, 1998).

Megfigyelhető tehát a racionális fogyasztás mellett a szimbolikus fogyasztás is, aminek egyik fajtája az önmegnyugtató fogyasztás, melynek célja önmagunk kényeztetése, jutalmazása, illetve az önmagunknak való örömszerzés. Másik fajtája az önkifejezô szimbolikus fogyasztás (Törốcsik, 1998). Sirgy és szerzőtársai (1997) négy énképet különböztetnek meg, az aktuális énképet, az ideális énképet, a társadalmi énképet és az ideális társadalmi énképet. Az aktuális énkép arra vonatkozik, ahogyan látja magát az egyén. Az ideális énkép azt mutatja, hogy milyennek szeretné látni magát az egyén. A társadalmi énkép jelenti azt, hogy milyen benyomást kelt másokban az egyén, míg az ideális társadalmi énkép az, amilyennek az egyén szeretné, hogy mások lássák.

Az önkifejező fogyasztás esetében tehát a márka lehet a fogyasztó személyiségének kifejezóeszköze, amit a fogyasztó önmaga megerősítésére használ. A márka személyisége ugyanis tükrözi a fogyasztó személyiségét, azonkívül a márka szolgálhat a fogyasztó gyenge személyiségjegyeinek kompenzálására is. Ebben az esetben a márka a fogyasztó vágyott személyiségét tükrözi (Márton, 2004).

A posztmodern gondolkodás, a korábban említettek szerint, a fogyasztást szimbolikus aktusnak tekinti
(Campbell, 1996). Baudrillard ezt úgy fogalmazza meg, hogy nem a termékek funkcióit vásárolják meg, hanem a termékhez kapcsolódó jeleket kapcsolják magukhoz a fogyasztók, ezáltal elérve a kívánt társadalmi státust. Az igény ezek alapján kulturális teremtménynek tekinthetố, melynek alapja az egyén vágyott csoportba való beilleszkedésének szándéka, azáltal, hogy magáévá teszi az adott csoport normáit, értékeit. A fogyasztás tehát nem más, mint ,jelek aktív manipulációja”, melynek során az egyén elfogadja a vágyott csoport kódjait, ezáltal beilleszkedik, és elkerüli a kirekesztettség veszélyét (Cherrier - Murray, 2004).

Ebben az értelemben tehát a javak fogyasztása, azok szimbolikus tartalma által, hasznossággal bír a fogyasztó számára, függetlenül attól, hogy magának a terméknek milyen funkcionális tulajdonsága van. A fogyasztás ezen funkcionalitástól elválasztott, pusztán társadalmi szerepén alapuló hasznossága már attól a ponttól jelentőséggel bír a fogyasztó számára, amikortól átlépte a létfenntartáshoz szükséges fogyasztási küszöböt. Ezen túlmenóen pedig, ahogy javul az egyén jövedelmi helyzete, egyre nagyobb jelentősége van a feltúnő fogyasztásnak (Shipman, 2004).

Bourdieu (1984) szintén szimbolikus tartalmat tulajdonít a fogyasztásnak, mivel véleménye szerint az egyén ízlése társadalmilag befolyásolt. Az egyén fogyasztásának tárgyával képes kifejezni bizonyos társadalmi osztályba való tartozását, és ezáltal más társadalmi osztályoktól való elkülönülését. Ebben az értelemben tehát a fogyasztó ízlése egyfajta „társadalmi fegyver", mellyel el tudja választani a kívánatost az ellenszenvestôl, az értékest az értéktelentól, legyen a fogyasztás tárgya akár étel vagy ital, vagy például kozmetikai cikk (Alan, 1994).

A fogyasztás szimbolikus jelentősége tehát tömören úgy fogalmazható meg, hogy ,az vagy, amit birtokolsz” (Belk, 1996: p. 65.).

A fent említettek alapján a szimbolikus fogyasztásnak komoly szerepe van a lojalitásban. Az alábbiakban igyekszem rámutatni a fogyasztásszociológia azon állításaira, melyek összefüggésbe hozhatóak a lojalitással, teszem ezt annak reményében, hogy talán közelebb lehet jutni ezen állítások segítségével a lojális fogyasztói magatartás magyarázatához, és esetleg a korábban említett problémák megoldhatóbbá válnak.

\section{A lojalitás fogyasztásszociológiai magyarázatai}

\section{Szimbólumok tartós és ismételt fogyasztása}

A szimbolikus fogyasztás fontos szerepet tölt be az egyén társadalmi elhelyezkedésében, akképpen, hogy a termékhez kapcsolt jelek által az egyén bizonyos cso- 
porttal közösséget vállal, egyúttal más csoportoktól elhatárolódik (Allen, 1994). Reichheld (2003) is kapcsolatot feltételez a vágyott imázs és a lojalitás közt, amennyiben ugyanis a termék fogyasztásával elérhetô társadalmi önkifejezố szerep megegyezik a vágyott szereppel, akkor ez többnyire a fogyasztó elégedettségéhez és lojalitásához vezet.

Fromm (1941) ezt a gondolatot egy igen érdekes kontextusban veti fel. Az emberben alapvetôen jelen van a törekvés valamely csoporthoz való tartozásra, és ezzel párhuzamosan jelen van a félelem a kirekesztettségtól. Ez a félelem gátolja az embert abban, hogy kilépjen az ismeretlenbe, tehát az adott jelek folyamatos elfogadása és az adott csoport kódrendszeréhez való alkalmazkodás teremti meg az egyén biztonságérzetét. A döntési szabadsággal ebben az értelemben együtt jár a bizonytalanság, a társadalmi elutasítás és a hibás döntéshozatal veszélye. Az egyén tehát a „szabadság elől a biztonságos konformitásba menekül". Fromm hozzáteszi, hogy az elfogadó, beilleszkedő egyén magát szabadnak érzi, nem érzékeli azt, hogy döntési szabadsága behatárolt.

Baudrillard (1990) egészen odáig megy, hogy megfordítható a birtoklási viszony az egyén és a termék között. Az egyénnek lehetôsége van objektumokat birtokolni, ezek az objektumok és szimbolikus tartalmuk az egyén identitásának meghatározó részét képezik. Ezáltal az a jel, mely a fogyasztóra és személyiségére utal, amely lényegében kifejezi identitását, elválik a fogyasztótól és az általa birtokolt objektumok képében ölt testet.

Ennek következtében az egyén függővé válik az általa birtokolt objektumoktól, ugyanis csak azok által képes kifejezni személyiségét. Ha az egyént „megszabadítanák" ezektôl az objektumoktól, azáltal elveszítené a korábban birtokolt értékeit, és kiszakadna az általa korábban vágyott közösségból, tekintve, hogy az egyének a jelek fogyasztásával határozzák meg saját személyiségüket és társadalmi helyzetüket. Ezen a ponton vélem összekapcsolhatónak a lojalitás és a fogyasztásszociológia tárgykörét, a fent leírtak alapján ugyanis a fogyasztó élete egyfajta folyamatos küzdelem, melyben a szimbolikus javak ismételt és folyamatos fogyasztásával - tulajdonképpen lojalitásával - törekszik az egyén arra, hogy elérje és megtartsa ideális énképét és ideális társadalmi énképét (Cherrier - Murray, 2004; Törôcsik, 1998; Kovács, 2005; Belk, 1996). Ennek értelmében tehát a lojalitás mögött az egyén folyamatos, szimbolikus énképfenntartása feltételezhető, ami merőben új megvilágításba helyezi a lojalitás tárgykörét, és számos új kutatási irány számára nyithat teret.

\section{Összegzés, értékelés}

Tanulmányomban kísérletet tettem arra, hogy a lojalitást egy újabb nézőpontból, a fogyasztásszociológia alapján vizsgáljam meg. Ez a fajta megközelítés sok tekintetben eltér a szakirodalom eddigi lojalitásvizsgálataitól. Célom az volt, hogy a lojalitásvizsgálatok problémáiból és ellentmondásaiból kiindulva egy olyan fogalmi keretbe helyezzem ezt a kérdést, mely magyarázatot adhat a fogyasztók magatartására, és döntéseik indokaira. Hitem szerint az egyén fogyasztásának szimbolikus tartalma az a fő motiváló tényezô, ami a lojalitáshoz vezet.

A XXI. század túlkínálati piacain a termelésról a fogyasztásra helyeződött át a hangsúly, ez utóbbi határozza meg a gazdasági folyamatokat. A javak szimbolikus tartalma társadalomszervezó erôvé vált. A társadalmi csoportok a közösen birtokolt és közösen értelmezett jelek és kódok által válnak koherenssé.

Ebben a megváltozott helyzetben a fogyasztók személyiségének és társadalmi helyzetének meghatározójává nem a termelésben, hanem a fogyasztásban betöltött szerepük vált. Ennek következtében, a fogyasztók az általuk megvásárolt és birtokolt javak szimbolikus tartalma által alakítják ki énképüket, identitásukat, valamint e szimbólumok által helyezik el magukat a társadalomban.

A fogyasztó az általa kialakított identitást igyekszik fenntartani, ezzel párhuzamosan pedig igyekszik folyamatosan demonstrálni az adott társadalmi csoportba való tartozását, ezzel elkerülve a kirekesztettség veszélyét. Ezt a törekvését azáltal tudja sikerre vinni, hogy ragaszkodik azokhoz a termékekhez, amelyek szimbolikus tartalmai személyiségének részévé váltak. Lojális tehát azokhoz a márkákhoz és termékekhez, melyek identitását reprezentálják, ugyanis e termékek nélkül személyisége és társadalmi szerepe eltávolodik az ideális énképétől, illetve az ideális társadalmi énképétól.

A lojalitás problémáinak pragmatikus megoldása nem volt célja tanulmányomnak, ez ugyanis további vizsgálatokat igényel. Amennyiben a szimbolikus fogyasztást és a személyiségalakítást mint motiváló tényezót tételezzük fel a lojalitás mögött, akkor ezek a problémák részben orvosolhatóvá válnak. Ezáltal ugyanis kitörhetünk a lojalitás vizsgálatának ágazati korlátaiból, mert a szimbolikus fogyasztás kevésbé függ attól, hogy milyen termék piacát vizsgáljuk, tekintve, hogy általánosabb megállapításokra juthatunk a szimbólumok jelentóségéról, függetlenül az adott szimbólum konkrét megjelenési formáitól. Szintén megoldhatónak látszik a dinamizálás problémája, az említettek 
alapján ugyanis a fogyasztó időben dinamikusan igyekszik fenntartani identitását, és a személyiségalakítás szimbolikus vizsgálata kifejezetten jó alapja lehet az intertemporális vizsgálatoknak.

A legfontosabb elôrelépést azonban abban látom, hogy fogyasztásszociológiailag jól magyarázhatóvá válik a korábban lojális fogyasztók márkaelhagyása. Ennek általam feltételezett egyik fó indoka lehet, hogy az idô előrehaladtával a fogyasztó számára egy másik termék vagy márka fogja megtestesíteni azt a szimbolikus jelentést, amire a fogyasztó vágyik. Ez a változás alapvetôen két okból is bekövetkezhet, egyrészt a márka megváltozott szimbolikus tartalmából, másrészt a fogyasztó megváltozott énképéből.

Tanulmányomat tehát indító jelzóvel illetném, mely arra utal, hogy egy kevésbé elterjedt gondolatkört kapcsol össze a lojalitással. Ennek velejárója, hogy nagyon alapos kutatást igényel bármiféle konkrét megállapítás vagy kijelentés. Célom a továbbiakban egyre mélyebben elmerülni a kérdésben, annak reményében, hogy sikerül rátalálni olyan fogyasztói döntést meghatározó aktorra, mellyel érthetóbbé válik ez az igen összetett és bonyolult folyamat.

Ennek jegyében az alábbiakban néhány tervezett kutatási területet ismertetek ezzel a témakörrel kapcsolatban.

\section{Érdekes kérdések, kutatási irányok}

- A már említett dinamizmus és intertemporalitással kapcsolatban kiemelten fontos az énkép változása, és ennek lojalitásra gyakorolt szerepe. Ha változik az énkép, tud-e változni vele a lojalitás tárgyát képezô márka akképpen, hogy továbbra is húséges maradjon a fogyasztó? A gyártók szempontjából ennél is lényegesebb kérdés, hogy egyáltalán érdemes-e változnia a márkának fogyasztójának énképével?

- Tanulmányomban kisebb hangsúlyt kapott, de korábbi vizsgálataimban gyakran foglalkoztam a kockázat jelentőségével. Ezzel kapcsolatosan érdemes lenne vizsgálatokat végezni, hogy fogyasztásszociológiai szempontból a lojális magatartás mennyiben csökkenti, illetve mennyiben növeli a fogyasztó kockázatérzetét.

- Szintén érdekes kérdés lehet annak vizsgálata, hogy az egyén ideális énképe által generált (belsô) lojalitás miért szúnik meg, és ennek indoka mennyiben különbözik az egyén ideális társadalmi énképe által generált (külsô) lojalitás megszúnésének indokaitól.

\section{Lábjegyzet}

${ }^{1}$ Az ,elégedettség csapdája” Reichheld (2000) szerint abból adódik, hogy a vállalat az elégedettségi mutató emelése érdekében a vevối többség akaratához igazodik, ahelyett, hogy elsôsorban a lojális kisebbség igényeit követné. Ennek könnyen lehet következménye a korábban lojális vevók elpártolása, tekintve, hogy nem az ô igényeiknek megfelelően alakult át a cég stratégiája, termelése. Így összességében az elégedettségi mutató emelkedik, azonban a profitabilis vevối csoport mérete csökken.

\section{Felhasznált irodalom}

Allen, D.E. (1994): Consumption and Social Stratification: Bourdieu's Distinction, Advances in Consumere Research, 1994, Vol 21, pp. 70-74.

Belk, R.W. (1996): Studies in the New Consumer Behaviour; Acknowledging consumption, edited by Daniel Miller, printed by Routledge, New York, USAISBN:0415106893 pp. 58-95.

Baudrillard, J. (1981): Towards a Critique of the Political Economy of the Sign. Mo: Telos Press, St. Louis

Baudrillard, J. (1988): Consumer Society, in Jean Baudrillard: Selected Writings, ed. Mark Poster, Politiy Press, Oxford

Baudrillard, J. (1990): Revenge of the Crystal: Selected Writings on the Modern Object and its Destiny, 19681983, eds. Paul Foss and Julian Pefanis, Concord, MA: Pluto Press

Bell, S.S. - Holbrook, M.B. - Solomon, M.R. (1991): Combining Aesthetic and Social Value to Explain Preferences for Product Styles with the Incorporation of Personality and Enseble Effects, Journal of Social Behavior and Personality, Vol 6. No. 6. pp. 243-274.

Bourdieu, P. (1984): Distinction: A Social Critique of the Judgement of Taste, trans. by R. Nice, Routledge and Kegan Paul, London

Campbell, C. (1996): The Sociology of Consumption; Acknowledging consumption, edited by Daniel Miller, Routledge, New York, pp. 96-126.

Cherrier, H. - Murray, J.B. (2004): The Sociology of Consumption: The Hidden Face of Marketing, Journal of Marketing Management, 2004/20 pp. 509-525.

Farkas, E. (2003): Érték(?)teremtés - Érték(?)esítés, Marketing\&Menedzsment, 2003/3. pp. 12-19.

Featherstone, M. (1991): Consumer Culture and Postmodernism, Sage, London

Fromm, E. (1941): Escape from Freedom, Holt, Rinehart and Winston, New York

Hámori, B. (2003): Kísérletek és kilátások Daniel Kahneman, Közgazdasági Szemle, L. évf., 2003. szeptember, pp. 779-799.

Hetesi E. - Rekettye G. (2005): A lojalitás dimenzióinak longitudinális mérése a hazai lakossági energiafogyasztók körében faktoranalízis alapján, Vezetéstudomány, 2005/ III. szám pp. 48-57. 
Hetesi E. (2002): Új dimenziók a lojalitás mérésében, Marketing\&Menedzsment 2002/IV. szám pp. 35-41.

Hetesi E. (2003): A minôség, az elégedettség és a lojalitás mérésének problémái a szolgáltatásoknál, és azok hatása a jövedelmezóségre, Marketing\&Menedzsment 2003/5. pp. 42-50.

Jaishankar, G. et al. (2000): Understanding the Customer Base of Service Providers: An Examination of the Differences Between Switchers and Stayers, Journal of Marketing, 2000/Vol 64, July pp. 65-87.

Kaplan, E.A. (1987): Rocking Around the Clock: Music, TV, Postmodernism and Consumer Culture, Methuen. London

Kovács E. (2000): A fogyasztói elégedettséget megalapozó szolgáltatásminőség, Marketing\&Menedzsment 2000/V. szám pp. 50-57.

Kovács K. (2005): Divattermékek és divatmárkák mint a szimbolikus fogyasztás eszközei, Marketing\&Menedzsment 2005, IV-V. szám pp. 72-82.

Márton A. (2004): Madarat tolláról, márkát fogyasztójáról, Marketing\&Menedzsment 2004/I. szám pp. 14-19.

McCracken, G. (1986): Culture and consumption: a theoretical account of the structure and movement of the cultural meaning of consumer goods, Journal of Consumer Research, 13. pp. 71-84.

Miller, D. (1996): Consuption as the Vanguard of History; Acknowledging consumption, edited by Daniel Miller, Routledge, New York, pp. 1-57.

Neal W.D. (1999): Satisfaction is nice, but value drives loyalty, Marketing Research, Spring 99, Vol 11, Issue 1.

Newman, K. (2001): The sorcerer's apprentice? Alchemy, seduction and confusion in modern marketing, International Journal of Advertising, 2001/20(4), pp. 409-429.

Oliver, R. L. (1999): Whence Consumer Loyalty?, Journal of Marketing Vol 63 pp. 33-44.

Reichheld, F.F. et al. (2003): Loyalty: A prescription for Cutting Costs, Marketing Management, Sept/Oct. 2003, Vol 12, Issue 5.
Reichheld,F.F.-Sasser, W.E. (1990):Zero defections:Quality Comes to Services, Harvard Business Review. Sept/Oct. pp. 105-111.

Reichheld, F. F. (1996): Learning from Customer Defections, Harvard Business Review, Mar/Apr96, Vol. 74.

Reichheld, F. F. (2000): The Loyalty Effect - The relationship between loyalty and profits, European Business Journal, 2000/III. pp. 134-139.

Reichheld, F. F. (2000): The Loyalty Effect - The relationship between loyalty and profits, European Business Journal, 2000/III. pp. 134-139.

Reichheld, F.F. (2003): The one number You need to grow, Harvard Business Review. Dec. pp. 47-54.

Reinartz, W. - Kumar, V. (2002): The Mismanagement of Customer Lolaty, Harvard Business Review, July. pp. 86-94.

Shipman, A. (2004): Lauding the Leisure Class: Symbolic Content and Conspicuous Consumption, Review of Social Economics, September pp. 277-288.

Sirgy, M.J. et al. (1997): Assessing the Predictive Validity of Two Methods of Measuring Self-image Congruance, Journal of Academy of Marketing Science, Vol. 25. No. 3. pp. 229-241. In. Kovács, K. (2005): Divattermékek és divatmárkák, mint a szimbolikus fogyasztás eszközei, Marketing\&menedzsment 2005, IV-V. szám pp. 72-82.

Solomon, M.R. (1988): Mapping product constellations: a social categorization approach to symbolic consumption, Psychology and Marketing, 5(3), pp. 233-258.

Törốcsik M. (1998): Funkcionális és szimbolikus fogyasztás, Marketing\&Menedzsment 1998/V. szám, pp. 45-50.

Veblen T. (1925): The Theory of the Leisure Class, George Allan and Unwi. London

Zeithaml V.A. et al. (2004): Customer-Centered Brand Management, Harvard Business Review, September, pp. 110-118.

Cikk beérkezett: 2008 . 1. hó

Lektori vélemény alapján véglegesítve: 2008. 3. hó

\section{E SZÁMUNK SZERZÖI}

Dr. Szabó József, főiskolai docens, Széchenyi István Egyetem, Győr; Dr. Görög Mihály, tanszékvezető egyetemi tanár, Budapesti Corvinus Egyetem; Dr. Neulinger Ágnes, tudományos munkatárs, Budapesti Corvinus Egyetem; Dr. Jászberényi Melinda, egyetemi docens, Budapesti Corvinus Egyetem; Prónay Szabolcs, egyetemi hallgató, Szegedi Tudományegyetem; Takács András, egyetemi tanársegéd, Pécsi Tudományegyetem 